\title{
Perceived Parental Involvement in the Academic Experience of Business Administration Students
}

\author{
MA Germina Esquivel-Santos
}

College of Management and Business Technology, Nueva Ecija University of Science and Technology, Philippines

\begin{abstract}
Parental involvement has been linked to a variety of positive outcomes for students.The study described the role of business administration students' parents' profession, employment, and business.This study employed a descriptive method and surveyed a total of 312 students from different majors of Business Administration. The researcher examined the parental involvement in the academic experiences of Business Administration students in terms of parents' profession, parents' employment, and parents' business. When students feel supported and loved by their parents, their self-confidence is boosted leading to feel competent in making job decisions later in life. Students perform better than their peers when their parents are financially capable. Thus, parent's financial status may contribute to the academic achievements of students.Regardless of their occupation, parents should retain their dedication or communication to their children. In terms of students' schoolwork, parents should always provide their children advice. In response, students must respect and honor their parents' occupations and businesses. In addition, parents must set aside time for their children to maintain the parent-child bond. Lastly, parents should assist their children in completing their education by making the appropriate arrangements to facilitate study. Future researchers should aim to do additional research on the elements that influence student academic experiences at different stages of education, such as primary and secondary school.
\end{abstract}

Keywords - Parental Involvement, Parents' profession, Parents' Employment, Parents' Business.

\section{INTRODUCTION}

Parental involvement has been linked to a variety of positive outcomes for students.By providing resources, opportunities, and suggestions that contribute to academic success through parental involvement, teacher-parent partnerships are likely to be strengthened (Shumow et al., 2011).
Parental engagement and communication at a high level contribute to the development of positive connections with teachers and the monitoring of a child's academic achievement (Barge \& Loges, 2003). Evidently, one study found that parents who were more involved in their children's education had higher academic achievement (Jeynes, 2008).

Further, Income, parental education level, household chores, and family environment all have an effect on a learner's academic progress. Due to their low income and lack of education, parents/guardians created an unfavorable home environment, as they were unable to provide the necessary materials and support for their children's academic success (Mauka, 2015).On the other hand, parental involvement in school improves parents' skills and knowledge (i.e., social capital), enabling them to better assist their children with school-related activities (Hill \& Taylor, 2004).

With these literatures, it is critical to understand the role of parents' profession, employment, and business in the academic experience of business administration students.

\section{OBJECTIVES OF THE STUDY}

The study examined the role of business administration students' parents' profession, employment, and business.

\section{METHODOLOGY}

This study employed a descriptive technique to collect data on the presentation of current conditions, to describe the essence of the situation as it was at the time of the study, and to analyze the causes of specific phenomena (Camic et al., 2003). A total of 312students of different majors of Business Administration of Nueva Ecija University of Science and Technology were surveyed in the study. The researcher used likert-scale questionnaires to ascertain respondents' perceptions through likert-scale responses (Vagias, 2006), as well as to evaluate the mean and weighted mean data. 


\section{RESULTS AND DISCUSSIONS}

Table 1. Role of Parents' Profession

\begin{tabular}{|cl|c|c|}
\hline \multicolumn{1}{|c|}{ Item Statement } & Mean & $\begin{array}{c}\text { Verbal } \\
\text { Interpretation }\end{array}$ \\
\hline 1. & The professions of your parents help to boost your confidence. & 4.30 & Strongly Agree \\
\hline 2. & Your parents have a lot of time for you regardless of their profession. & 3.08 & Agree \\
\hline 3. & Your parent professions inspired you to be better in school. & 3.44 & Strongly Agree \\
\hline $4 . \quad$ The professions of your parents give pressure to your academic performance. & 2.80 & Agree \\
\hline $5 . \quad$ Your parents help you on your pressure to your academic performance. & 3.16 & Agree \\
\hline $\begin{array}{l}\text { 6. } \\
\text { Your parents help you on your assignments, projects and activities in school } \\
\text { regardless of their busy schedule. }\end{array}$ & 2.90 & Agree \\
\hline & Average Weighted Mean & 3.28 & Strongly Agree \\
\hline
\end{tabular}

Table 1 presents the result of how the role of parents' profession affect the academic experience of the Business Administration students. Students got an average weighted mean of 3.28 that has a verbal interpretation of "Strongly Agree". This means that the parents' profession has affected the students' academic experiences. In addition, the respondents strongly agreed on Statement 1 "The professions of your parents help to boost your confidence" $($ Mean $=4.30)$ and Statement 3 "Your parent professions inspired you to be better in school." (Mean = 3.44). This confirms that when students feel supported and loved by their parents, they have more faith in their own capacity to investigate careers and select one that is interesting and exciting to them. This is significant because research shows that adolescents who feel competent in making job decisions later in life make happier choices (Keller $\&$ Whiston, 2008).

Table 2. Role of Parents' Employment

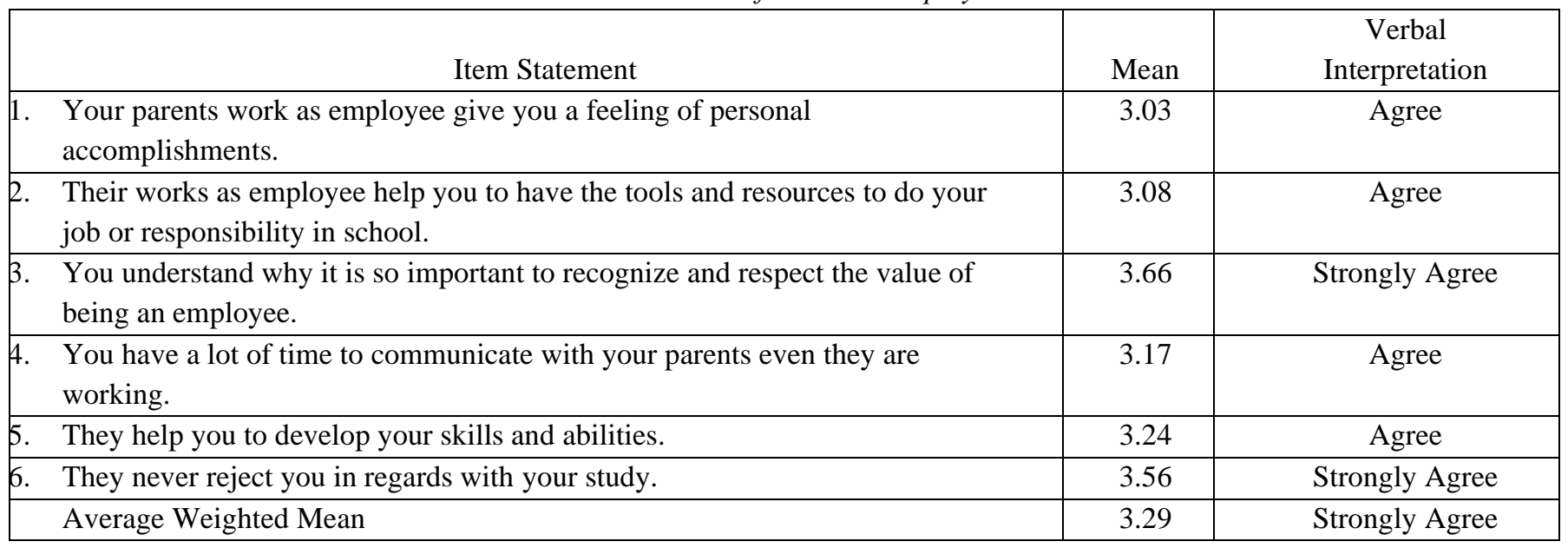

Table 2 presents the result of how the role of parents' employment affect the academic experience of the Business Administration students. Students got an average weighted mean of 3.29 that has a verbal interpretation of "Strongly Agree". This data means that parents' employment has affected the academic experience of the students. They also strongly agreed on Statement 3 "You understand why it is so important to recognize and respect the value of being an employee." (Mean = 3.66) and Statement 6 "They never reject you in regards with your study." (Mean = 3.56). The results are in alignment to the study of Brand (2015) that children's self-esteem and wellbeing have been connected to parental unemployment, as well as higher school dropout rates, lower academic expectations, worse educational attainment, and poorer health. 
Table 3. Role of Parents' Business

\begin{tabular}{|c|c|c|}
\hline Item Statement & Mean & $\begin{array}{c}\text { Verbal } \\
\text { Interpretation }\end{array}$ \\
\hline $\begin{array}{l}\text { 1. Your parents business distracts you while you are doing or reviewing your } \\
\text { lessons. }\end{array}$ & 2.57 & Agree \\
\hline $\begin{array}{l}\text { 2. Your parents give time attending general meeting on your school regardless } \\
\text { of their business. }\end{array}$ & 2.93 & Agree \\
\hline 3. Your parents' business affects your academic performance. & 2.42 & Agree \\
\hline $\begin{array}{l}\text { 4. Because of your parents business, it's hard for you to communicate with } \\
\text { them. }\end{array}$ & 2.22 & Agree \\
\hline 5. Your parents business inspired you to be better in school. & 3.13 & Agree \\
\hline 6. Your parents help you a lot in enhancing your skills and learnings. & 3.13 & Agree \\
\hline Average Weighted Mean & 2.73 & Agree \\
\hline
\end{tabular}

Table 3 presents the result of how the role of parents' business affect the academic experience of the Business Administration students. Students got an average weighted mean of 2.73 that has a verbal interpretation of "Agree". They agreed to Statement 5 "Your parent's business inspired you to be better in school." and Statement 6 "Your parents help you a lot in enhancing your skills and learnings.", which both statements got a mean of 3.13. According to Henderson and Berla (1994) students perform better than their peers when their parents are financially capable and also provide spiritual support to their children by directing their reading at home. Although it has been maintained that the extent to which the family is interested in the child's education, rather than the family's income, is the most accurate predictor of students' achievement.

\section{CONCLUSIONS AND RECOMMENDATIONS}

The researcher examined the parental involvement in the academic experiences of Business Administration students in terms of parents' profession, parents' employment, and parents' business. When students feel supported and loved by their parents, their self-confidence is boosted leading to feel competent in making job decisions later in life. Students perform better than their peers when their parents are financially capable. Thus, parent's financial status may contribute to the academic achievements of students.

Regardless of their occupation, parents should retain their dedication or communication to their children. In terms of students' schoolwork, parents should always provide their children advice. In response, students must respect and honor their parents' occupations and businesses. In addition, parents must set aside time for their children to maintain the parent-child bond. Lastly, parents should assist their children in completing their education by making the appropriate arrangements to facilitate study. Future researchers should aim to do additional research on the elements that influence student academic experiences at different stages of education, such as primary and secondary school.

\section{REFERENCES}

[1] Barge, J. K., \& Loges, W. E. (2003). Parent, student, and teacher perceptions of parental involvement. Journal of Applied Communication Research, 31(2), 140-163.

[2] Brand, J. E. (2015). The far-reaching impact of job loss and unemployment. Annual review of sociology, 41, 359-375.

[3] Camic, P. M., Rhodes, J. E., \& Yardley, L. E. (2003). Qualitative research in psychology: Expanding perspectives in methodology and design. American Psychological Association.

[4] Henderson, A. T., \&Berla, N. (1994). A new generation of evidence: The family is critical to student achievement.

[5] Hill, N. E., \& Taylor, L. C. (2004). Parental school involvement and children's academic achievement: Pragmatics and issues. Current directions in psychological science, 13(4), 161-164.

[6] Jeynes, W. H. (2008). Effects of parental involvement on experiences of discrimination and bullying. Marriage \& Family Review, 43(3-4), 255268.

[7] Keller, B. \&Whiston, S. (2008). The Role of Parental Influences on Young Adolescents' Career Development. Journal of Career Assessment - J CAREER ASSESSMENT. 16. 198-217. $10.1177 / 1069072707313206$.

[8] Mauka, A. M. (2015). Parental involvement and its effects on students' academic performance in public secondary schools in Korogwe, Tanzania (Doctoral dissertation, The Open University Of Tanzania).

[9] Shumow, L., Lyutykh, E., \& Schmidt, J. A. (2011). Predictors and Outcomes of Parental Involvement with 
High School Students in Science. School Community Journal, 21(2), 81-98.

[10] Vagias, W. M. (2006). Likert-type scale response anchors. clemson international institute for tourism. \& Research Development, Department of Parks, Recreation and Tourism Management, Clemson University. 